\title{
Tafsir Historis Kritis: Mengungkapkan Kasih Allah Yang Menyembuhkan Dalam Kitab Hosea 14:1-10
}

Dibuat untuk memenuhi tugas ujian akhir semester 4

Mata Kuliah: Tafsir Perjanjian Lama II

Dosen Pengampu: Dr. Firman Panjaitan, M.Th

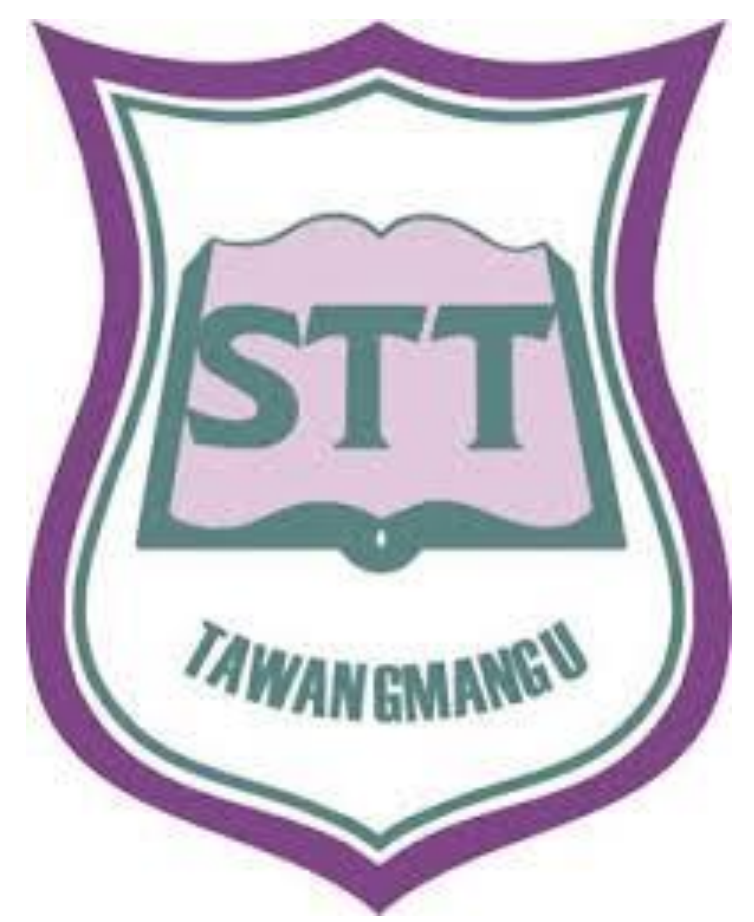

Oleh:

Nama: Pipit Hastari Budiarto

NIM: 396819

PROGRAM STUDI TEOLOGI

SEKOLAH TINGGI TEOLOGI TAWANGMANGU

KARANYANYAR 


\section{LATAR BELAKANG KITAB HOSEA}

\section{Situasi (Sosial, Politik, Keagamaan)}

Kira-kira satu dasawarsa setelah Amos datang ke Utara untuk mengecam pemerintah Yerobeam, Allah memanggil Hosea dari kerajaan Utara untuk melayani sebagai Nabi. Pemberitaan selama bertahun-tahun memperlihatkan kasih karunia dan penghukuman Allah. Kitab Hosea dipilih sebagai kitab pertama dalam kumpulan kitab nabi kecil bukan hanya karena dia adalah nabi di awal, akan tetapi juga dikarenakan kitab ini termasuk sebagai kitab terpanjang dari kitab yang ditulis pada sebelum masa pembuangan. Pelayanan Hosea pada masa pemerintahan Uzia, Yotam, Ahas dan Hizkia di Yehuda dan di Yerobeam II di Israel. Masa pelayanan Hosea pada masa itu adalah sekitar 40 tahun, dikarenakan Yerobeam wafat kira-kira tahun 753 SM dan Hizkia naik tahta kira-kira tahun 715 SM sesudah menjadi raja bersama sejak kira-kira tahun 728 SM. $^{1}$ Kitab Hosea sendiri tidak memberi bukti bahwa Hosea terus menyampaikan Firman Allah. Pada waktu anak sulungnya lahir, dinasti Yehu masih berkuasa karena Allah berkata keluarga Yehu masih akan di hukum tetapi tidaklah pasti yang menjadi penguasa pada saat itu adalah Yerobeam II atau anaknya. ${ }^{2}$

Pada tahun 930 SM, kerajaan kesatuan Daud dan Salomo terbagi menjadi dua kerajaan, yaitu kerajaan Israel di utara dan kerajaan Yehuda di Selatan. Kedua kerajaan ini menonjol dalam pelayanan kenabian Hosea. Pada masa itu, umat Allah juga berinteraksi dengan negara-negara lain seperti Aram dan Mesir. Tetapi di atas segalanya, Hosea memfokuskan pelayanannya pada peristiwa-peristiwa yang melibatkan kerajaan Asyur. Pada zaman Hosea Asyur menjadi kerajaan adi kuasa yang memperluas pengaruhnya ke segala penjuru, termasuk tanah Israel dan Yehuda. Pelayanan Hosea dimulai di kerajaan Utara Israel, hamper kurang lebih dua ratus tahun setelah Israel terpisah dari Yehuda.

Tinggal di Israel utara selama periode sejarah ini menjadi hal yang sangat sulit untuk siapa saja yang berusaha berlaku setia kepada Allah. Dan hal ini juga berlaku untuk Hosea, seorang abdi Allah yang dipanggil menjadi nabi. Hosea menyaksikan secara langsung bagaimana para pemimpin Israel menjauhkan kerajaan mereka dari Tuhan dan mengandalkan aliansi dengan bangsa-bangsa lain dan ilah-ilah mereka. Para Imam Israel menggabungkan ibadah kepada Allah dengan ritual-ritual kesuburan dalam kemabukan dan hawa nafsu yang terkait dengan penyembahan berhala. Orang kaya menjadi semakin kaya, akan tetapi orang yang miskin menjadi begitu miskin sehingga mereka seringkali harus menyerahkan istri dan putri-putri mereka ke kuil prostisusi hanya supaya mereka bisa melanjutkan hidup, karena pemerintah pada saat itu menekan istri-istri dan putri-putri orang miskin agar melakukan prostitusi di pusat-pusat pemujaan kesuburan mereka. Dan ketika Hosea menghadapi kondisi yang memilukan hati yang terjadi di kerajaan utara Israel ini, Allah memanggilnya untuk bernubuat, untuk menyampaikan pesan dari Tuhan namun hanya sedikit orang saja yang ingin mendengarkannya. Allah akan menjatuhkan kutuk atas kerajaan Israel melalui Asyur. Sebagai utusan kenabian, dalam nubuatannya berkaitan dengan kutuk atas Israel, sebenarnya Hosea hendak menyatakan bagaimana Allah bermaksud menerapkan perubahan perjanjian

\footnotetext{
${ }^{1}$ W.S Lasor dkk. 2004. Pengantara Perjanjian Lama 2( Jakarta: BPK Gunung Mulia)

2 J. Philip King, dkk. 2012. Kehidupan Orang Israel Alkitabiah (Jakarta: BPK Gunung Mulia)

${ }^{3}$ Thirdmill. 2007. Hikmat Nubuat Hosea (Casselberry: Third Millenium Ministries), HIm.2
} 
dari kebajikan ilahi, kesetiaan manusia dan konsekuensi dari berkat dan laknat sehubungan dengan kebangkitan Asyur.

\section{Penulis Kitab Hosea}

Mengenai kepenulisan kitab Hosea penulis meyakini bahwa kitab Hosea ditulis oleh seorang yang bernama Hosea. Hal tersebut di tunjukkan dalam ayat pendahuluan dari kitab tersebut, yaitu Hosea 1:1. Hosea merupakan anak laki-lai dari seorang Beeri yang menjadi penduduk Israel selama abad keemasan di bawah kepemimpinan Raja Yerobeam II. Meskipun beberapa penafsir menganggap kitab Hosea ditulis oleh penulis yang berbeda. Hal tersebut dikarenakan adanya perubahan isi dan gaya kepenulisan yang terdapat dalam pasal 13 dan $4-14 .^{4}$

Hosea memulai pelayanannya setelah Amos, nama Hosea memiliki arti Keselamatan ada pada Tuhan atau Tuhan adalah keselamatan. Seperti yang sudah dijelaskan pada bagian waktu dan penulisan Hosea dia melayani pada masa pemerintahan Uzia, Yotam, Ahas, Hizkia, raja-raja Yehuda, dan Yerobeam II, Raja Israel. Uzia memulai pemerintahannya sekitar tahun $767 \mathrm{SM}$, sedangkan Yerobeam II wafat pada tahun 753 SM. dari hal ini kita bisa memperkirakan awal masa pelayanan Hosea sekitar tahun $760 \mathrm{SM}^{5}$

Dengan demikian penulis lebih setuju dengan pernyataan bahwa kitab Hosea di tulis oleh seorang yang bernama Hosea bin Beeri (1:1) nabi utusan Allah. Mengapa demikian? Karena penulis melihat jangka pelayanan Hosea yang sangat panjang sangat memungkinkan Hosea menulis kitabnya ketika ia melayani, sehingga kitabnya menjadi hikmat bagi Hizkia. Allah tidak menyatakan semua nubuatan Hosea pada waktu yang bersamaan, Allah memberikan penyataan-penyataan kepada Hosea ketika kerajaan Israel menghadapi bangkitnya Asyur ke ujung kekuasaan pada tahun 722 SM, pendudukan Ayur pada tahun 732 SM dan pendudukan Asyur pada tahun 722 SM. dengan demikian jika kita memandang dari keberagaman segi historis kita bisa melihat bahwa pandangan profetik Hosea berubah seiring bergulirnya waktu, karena ia berbicara dalam situasi yang sedang berubah. Dan kita juga harus memperhatikan bahwa Hosea menyusun nubuat-nubuatnya berdasarkan topik yang dibahasnya, jadi hal ini mementahkan argumen jika Hosea ditulis oleh penulis yang berbeda-beda. Jika kita memperhatikan dengan seksama Hosea 1: 1 merupakan judul kitab ini dan dimaksudkan untuk memperkenalkan rentang waktu seluruh pelayanan dari Hosea, dan sedangkan Hosea 14:10 mengakhiri kitab ini dengan kalimat penutup yang merangkum semua tujuan Hosea, yaitu mengajak umat Allah agar memperoleh hikmat dari kitabnya. ${ }^{6}$

\section{Waktu dan Penulisan}

\footnotetext{
${ }^{4}$ Christine V. Dawan \& Firman Panjaitan. 2018. Kasih Setiaa Khesed, Hosea 6:4-6 (Yogyakarta: Diandra Kreatif), HIm. 46

${ }^{5} \mathrm{Ibid} . \mathrm{HIm} .48$

${ }^{6}$ Ibid. HIm 15
} 
Daftar raja-raja yang disebutkan dalam Hosea 1:1 merupakan pedoman untuk memperkirakan awal dan akhir masa pelayanan Hosea, serta kapan waktu penulisannya. Dari daftar ini kita bisa mengetahui bahwa pelayan Hosea dimulai pada zaman Uzia, yang juga dinamakan Azarya yang memerintah di Yehuda sekitar tahun 792-740 SM. dan Yerobeam II bertahta sekitar tahun 793-753 SM. sebagian besar penafsir dengan tepat menyatakan bahwa keadaan yang diceritakan dalam nubuat-nubuat Hosea yang paling awal mencerminkan keadaan di Israel selama satu dekade terakhir pemerintahan Yerobeam II. Jadi, masuk akal apabila dikatakan bahwa pelayanan Hosea dimulai sekitar 760 SM. ini memungkinkan menjadikan Hosea menjadi salah satu dari nabi-nabi yang paling awal, dengan sebuah kitab biblika yang khusus dalam pelayanannya. Di sisi lain, daftar raja-raja dalam Hosea 1:1 juga memberikan kita sebuah perkiraan tentang akhir masa pelayanan kenabian Hosea. Hosea melayani sepanjang pemerintahan raja-raja Yehuda, Uzia, Yotam dan Ahas, dan dia mengakhiri pelayanannya selama pemerintahan Hizkia.

Setelah memerintah bersama ayahnya selama beberapa waktu, Hizkia adalah satusatunya penguasa Yehuda sekitar tahun 715-686 SM. kita tidak dapat memastikan berapa lama Hosea hidup selama pemerintahan Hizkia, namun seandainya dia memulai pelayanannya sekitar 760 SM pada usia 20 tahun, maka dia akan berusia 94 tahun pada tahun 686 SM. jadi kemungkinan besar pelayanan Hosea berakhir sebelum tahun 686 SM. jadi amanlah bila mengatakan tanggal yang paling awal untuk penulisan kitab Hosea adalah sekitar kurun waktu pemerintahan Hizkia sebagai penguasa tunggal yang dimulai pada tahun 715 SM dan berakhir pada tahun 686 SM. dengan demikian penulis bisa mengatakan kepenulisan kitab Hosea dituliskan sebelum masa pembuangan sampai sebelum berakhirnya masa pembuangan.

\section{Latar Belakang Hosea 14: 1-10}

Pada masa itu bangsa Israel tengah berada di dalam masalah akibat kesalahan yang telah mereka perbuat. Karena kekayaan dan kemakmuran di bangsa itu menimbulkan kesombongan, ketamakan dan egoisme sehingga bangsa Israel mengalami sebuah kemerosotan secara moral (Hos. 9:9) bahkan juga mengalami kerusakan secara tatanan sosial (Hos. 4:2,18; 6:8-9; 7:1). Keadaan tersebut bisa dibuktikan dari kemurtadan yang telah dilakukan oleh bangsa Israel. Di mana mereka meninggalkan Tuhan yang telah menuntun mereka bebas dari sebuah perbudakan dan mereka berpaling kepada para Baal, mereka mengalami penyembahan berhala dan kejahatan yang hebat (Hos. 10:15; 4:17; 7:16; 11:2; 13:1-2). Kemerosotan yang dialami oleh kerajaan Utara setelah kematian Yerobeam II telah membuktikan ucapan Hosea terkait tuduhan ilahi dan putusan dari Allah. ${ }^{7}$

Dalam Hosea 11:1-14:8, ayat ini menampilkan penyataan-penyataan yang diterima Hosea ketika dia menyampaikan nubuatannya tentang pendudukan Asyur pada tahun 722 SM. pada saat itu raja telah memimpin Israel dalam penyembahan berhala dan ketidakadilan. Namun dia berusaha melepaskan diri dari Asyur dengan mencari Aliansi dengan Mesir. Allah secara khusus berbicara tentang hal ini dalam pasal 11:5, di mana ia mengatakana bahwa Israel "tidak akan kembali lagi ke tanah Mesir, dan Asyur tidak akan menjadi raja mereka (ESV)". Konteks historis ini juga diteguhkan oleh fakta dlam 11:12 dan 12:2-6. Jika kita melihat dalam Hosea 12:3 TUHAN memiliki perbantahan dengan Yehuda, meskipun Hizkia berhasil mencapai perubahan yang besar, ia mengandalkan kekuatannya sendiri dengan membangun aliansi dengan Mesir daripada ia harus berbalik kepada Tuhan. ayat-ayat ini

\footnotetext{
${ }^{7}$ Andrew E. Hill, John H Walton. 2013. Survei Perjanjian Lama (Malang: Gandum Mas), hlm 584
} 
menyajikan pola Hosea, dimana Israel telah berdosa kepada Allah. Berulangkali Allah memanggil mereka, namun mereka semakin pergi jauh dari hadapan Allah dan sebagai akibatnya penghakiman akan tiba bagi mereka. Namun dalam pasal 14 ini Allah tetap menunjukkan kasih-Nya dengan memberikan peringatan dan pengharapan bagi masa depan Israel melalui Hosea. ${ }^{8}$

\section{PEMBAHASAN}

\section{Teks dan Transliterasi}

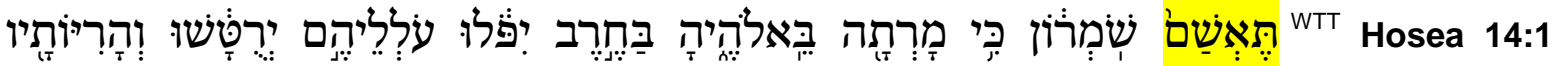

יביקוקו:

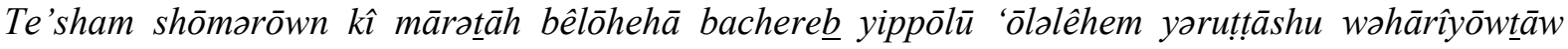
yəobuqqā' $\bar{u}$

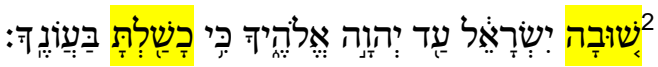

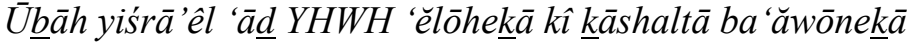

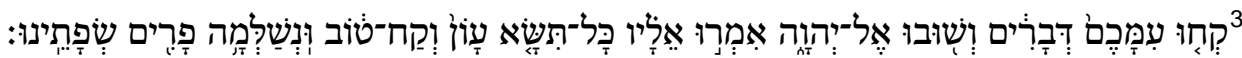

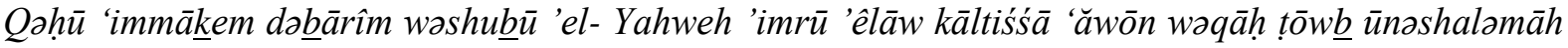
pā-rîm śapātanū

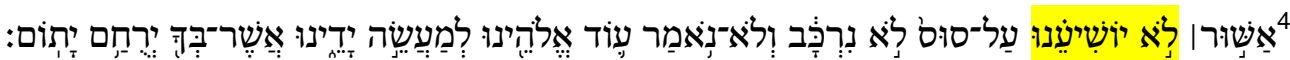

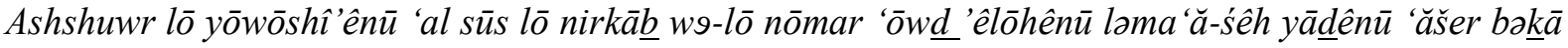
yərucham yātōom

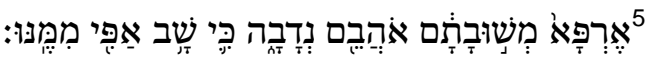

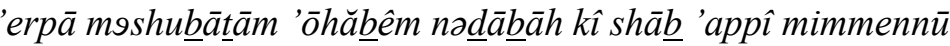

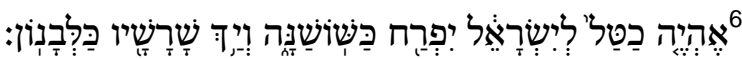
'ehyeh kațtal layiśrā'êl yipraḥ kashshōwoshannāh wayak shārāshāw kalla bānōwn

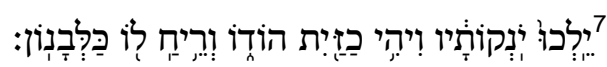

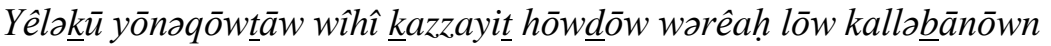

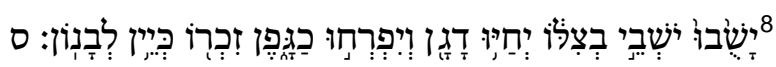

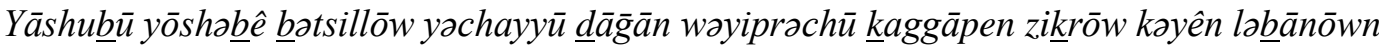

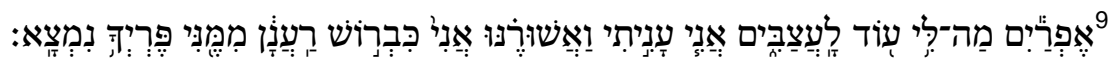

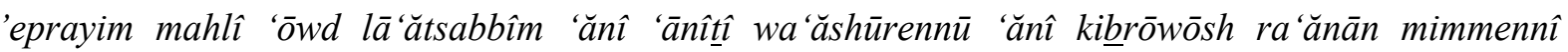
perya $\underline{k} \bar{a}$ nimts $\bar{a}$

\footnotetext{
${ }^{8}$ Thirdmill. 2007. Hikmat Nubuat Hosea (Casselberry: Third Millenium Ministries), HIm.30
} 


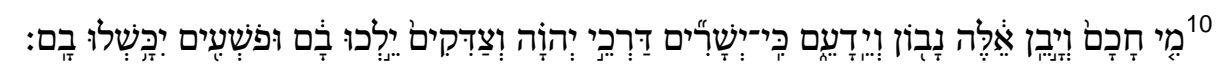

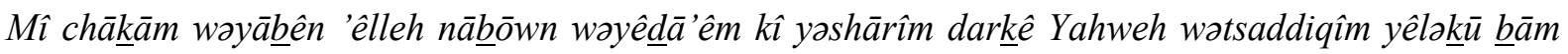
üpōsha 'îm yikkāshalū bām

\section{Kritik dan Analisa Teks}

Dalam ayat 1, kata תֶֶּׁ dalam ITB diterjemahkan menjadi "Harus mendapat", menurut penafsir terjemahan ini dirasa kurang tepat, karena jika diperiksa dalam bentuk bahasa aslinya, kata ini merupakan kata kerja imperfect, yang menjelaskan bahwa hukuman yang diterima itu belumlah sempurna. Jika dibandingkan dengan terjemahan NIV, versi dari terjemahan ini lebih memilih untuk menerjemahkan menjadi Must. Dalam penggunaan kata ini NIV berusaha menjelaskan bahwa mendapatkan hukuman itu menjadi sebuah keharusan dan pasti terjadi. Sedangkan dalam terjemahan KJV ia mengunakan kata Shall, dan NAS menggunakan kata Will, kedua terjemahan ini berusaha menjelaskan bahwa penghukuman merupakan sesuatau yang akan ditanggung oleh Samaria. Dan dengan beberapa perbandingan terjemahan tersebut sebagai pertimbangan, penafsir memutuskan untuk lebih memilih untuk menerjemahkan menjadi "Akan menanggung hukuman" sedikit berbeda dengan terjemahan yang dihasilkan oleh ITB, karena dinilai lebih mendekati makna yang terdapat dalam bahasa aslinya.

Dalam ayat 2, kata שְִָּבה dalam ITB diterjemahkan sebagai "Bertobatlah" yang memang jika dilihat dalam nbahasa aslinya, kata ini diposisikan sebagai kata kerja dalam bentuk perintah. Jika dibandingkan dengan terjemahan KJV, NIV dan NAS, ketiga terjemahan ini kompak memilih menerjemahkannya menjadi return, yang artinya kembalilah. Jika membandingkan terjemahan yang dihasilkan, penafsir lebih setuju dengan hasil terjemahan dari KJV, NIV dan NAS, dikarenakan jika melihat kondisi Samaria pada saat itu, mereka dahulunya memanglah bangsa yang telah mengenal dan menikmati berbagai pertolongan Tuhan, tetapi mereka gagal untuk setia dan memutuskan untuk meninggalkan Tuhan dan berpaling kepada Baal atau penyembahan berhala.

Selain itu dalam ayat yang sama juga terdapat kata yang tidak kalah menarik, yaitu

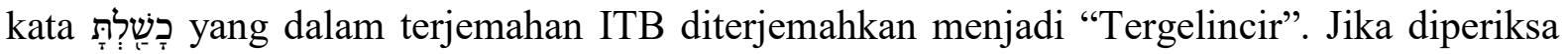
dalam bahasa aslinya, kata ini merupakan kata kerja yang sudah sempurna, artinya bentuk dari kata ini berusaha menjelaskan bahwa kata kerja ini pernah terjadi masa lalu karebna diakibatkan oleh suatu aksi atau situasi yang pernah dimulai di masa lalu, namun telah berhenti pada suatu titik tertentu di masa lalu. Dalam terjemahan KJV, kata ini diterjemahkan menjadi hast fallen atau "Telah jatuh". Sedangkan dalam NIV kata ini diterjemahkan sebgai down fall atau "kejatuhan" dan dalam NAS diterjemahkan menjadi have stumbled atau "tersandung".

\section{Terjemahan}

1. "Samaria akan menanggung hukuman karena tidak taat kepada Allahnya. Mereka akan rebah karena pedang, anak-anaknya akan dihancurkan dan perempuanperempuannya akan dirobek perutnya." 
2. "Kembalilah hai Israel kepada TUHAN Allahmu sebab kamu telah tersandung dalam rasa bersalahmu."

3. "Bawalah serta perkataanmu dan kembalilah kepada TUHAN! Katakanlah kepadaNya, buanglah segala kesalahan dan ambilah sesuatu yang baik, maka kami akan menghadiahkan lembu muda dan pengakuan kami."

4. "Assyur tidak akan menyelamatkan kami. Kami tidak mau menunggangi kuda dan tidak akan berkata lagi: ya Allah kami! Terhadap pekerjaan tangan kami, karena Engkau menunjukkan belas kasihan ditengah-tengah anak yatim."

5. "Aku akan menyembuhkan kemurtadan mereka, au akan mengasihi mereka dengan sukarela, karena kemarahan-Ku telah surut dari pada mereka."

6. "Aku akan menjadi seperti embun pagi Israel, ia akan mekar seperti bunga lili dan berakar seperti pohon Lebanon."

7. "Ranting-rantingnya akan menyebar, keindahannya akan seperti pohon zaitun dan harumnya seperti Lebanon."

8. "Mereka akan kembali diam di dalam naungan-Ku dan hidup kembali seperti gandum, mereka akan berumbuh seperti pohon anggur yang termahsyur seperti anggur Lebanon."

9. "Efraim, apakah hubungan-Ku dengan berhala-berhala? Aku yang menjawab dan memelihara kamu! Aku seperti pohon cemara yang hijau, daripada-Ku kamu mendapat buah!."."

10. "Siapakah yang bijaksana? Biarlah ia memahami ini. Apapun yang dipahaminya ia akan mengetahuina. Karena jalan-jalan TUHAN benar dan orang benar berjalan di dalamnya, tetapi pemberontak akan tersandung di dalamnya."

\section{Tafsir Hosea 14:1-10}

Pada pasal 14 ini, Hosea hadir dengan beritanya bahwa kemurahan hati TUHAN yang luar biasa akan mengubah Israel. Pada bagian ini, pasal 14 merupakan puncak dari khotbahkhotbah kenabian Hosea, dimana secara tidak langsung Hosea ingin menyampaikan kepada umat Israel, bahwa agar dapat memohon dan menyingkapkan kebaikan hati yang penuh kasih dari pribadi TUHAN, Israel harus mampu bertobat, dengan cara kembali kepada Tuhan dan meninggalkan penyembahan berhala. Dengan memanjatkan doa sebagai wujud dibangunnya kembali atau re-connecting hubungan antara TUHAN dan Israel. Israel dapat meletakkan harapannya lagi kepada rasa iba dan kepastian dari TUHAN yang telah mengikat perjanjian kepada mereka, yang mengampuni kejahatan, sebagaimana yang telah dinyatakan oleh TUHAN kepada Musa di padang gurun (Kel. 34:6).

Pasal terakhir Hosea ini menyingkapkan iman sang nabi akan kesediaan TUHAN yang murah hati untuk menerima pertobatan dari umat-Nya dan memulihkan hubungan perjanjian mereka dengan-Nya kembali. Dengan kondisi hancurnya kerajaan Utara yang menyedihkan pada saat itu, selama mereka mendapatkan serangan yang menghancurkan dari Asyur, pada bagian ini Hosea menawarkan permohonan untuk kembali kepada TUHAN dengan doa yang bertobat sebagai cara untuk mendekati TUHAN dan hal yang menakjubkan adalah tanggapan Tuhan dengan gaya iramanya dan kata kerja orang pertama yang tegas dalam Hosea 14:6-10. Hosea 14 mengingat kembali tentang nubuat keselamatan yang terdapat dalam Mazmur 91:14-16, di mana tujuh kata kerja tunggal pertama menggambarkan tindakan pengampunan TUHAN dan juga menjanjikan penyembuhan atas ketidaksetiaan di masa lalu. Pasal-pasal terakhir Hosea juga merupakan ringkasan dari doa yang lebih awal terdapat dalam Hosea 6:1-3, di mana tanggapan Allah merupakan penghakiman yang lebih 
lanjut (6:4-5), menghukum kemarahan (8:5), dan penolakan (9:17). ${ }^{9}$ Di sini sebaliknya, gambaran yang kaya dari sang nabi menggambarkan dampak dari kasih penebusan-Nya.

Ada kata yang sama dan menarik yang digunakan antara Hosea 14 dan Hosea 11, yaitu "kembali" (14:1-2; 11:5, 11), "Menyembuhkan" (14:4; 11:3), "Kasih" (14:44; 11:1,4), dan "Kemarahan" (14:4, 11:9). Jika kita memperhatikan penggunaan kata tersebut, kita akan melihat bahwa, Hosea 14 merupakan perjuangan batin Allah yang telah memberikan jalan menuju penyataan keselamatan. Dari pesan yang terdapat dalam pasal ini, bisa dikatakan bahwa kehancuran Israel pada masa itu bukanlah akhir dari segalanya, tetapi masih ada tawaran visi yang penuh dengan harapan tentang pemulihan yang diberikan oleh Allah. ${ }^{10}$

Dalam ayat pertama, dikatakan bahwa Samaria akan menanggung hukuman karena tidak taat kepada Allahnya. Kesalahan apa yang diperbuatnya dan bentuk ketidaktaatan apa yang dilakukakknya sehingga ia harus menanggung hukuman dari Allah? Mereka bersalah karena mengandalkan kekuatannya sendiri dengan bergantung kepada Asyur dan bukan Allah. Meskipun Asyur mampu memberikan kemakmuran bagi mereka, tetapi justru itu membawa petaka bagi mereka karena semakin membuat mereka tidak taat kepada Allah. Karena kekayaan dan kemakmuran di bangsa itu menimbulkan kesombongan, ketamakan dan egoisme sehingga bangsa Israel mengalami sebuah kemerosotan secara moral (Hos. 9:9) bahkan juga mengalami kerusakan secara tatanan sosial (Hos. 4:2,18; 6:8-9; 7:1). Keadaan tersebut bisa dibuktikan dari kemurtadan yang telah dilakukan oleh bangsa Israel. Di mana mereka meninggalkan Tuhan yang telah menuntun mereka bebas dari sebuah perbudakan dan mereka berpaling kepada para Baal, mereka mengalami penyembahan berhala dan kejahatan yang hebat (Hos. 10:15; 4:17; 7:16; 11:2; 13:1-2). Dan hal inilah yang menyebabkan mereka harus menanggung hukuman dari TUHAN.

Kemudian dalam ayat kedua, dikatakan "Kembalilah hai Israel kepada TUHAN Allahmu, sebab kamu telah tersandung dalam rasa bersalahmu." Pada bagian ini diawali dengan sebuah kata perintah yaitu "Kembalilah" hal itu menunjukkan bahwa TUHAN sangat menolak untuk kembali kepada hubungan perjanjian tersebut, tetapi panggilan TUHAN tersebut berbicara mengenai hasratnnya untuk menyembuhkan Israel. Desakan tegas yang TUHAN berikan di sini menuntut pertobatan dari pengakuan yang tulus dan menjanjikan sebuah keselamatan. ${ }^{11}$ Lalu apa yang menyebabkan mereka tersandung dalam rasa bersalah? Pada saat itu, Israel telah dipikat oleh penyembahan berhala dan tidak mungkin bisa bangkit dari obsesinya tanpa bantuan dari TUHAN melalui keibaan hati-Nya. Kesalahan yang telah mereka perbuat terhadap TUHANlah yang menjadi batu sandungan mereka. Mengandalkan diri sendiri, ketidaksetiaan mereka terhadap jalan yang TUHAN berikan, membawa mereka menikmati sebuah kehancuran dan penghukuman yang pasti. Tidak bisa dipungkiri, hal ini pasti membuat mereka mengalami penyesalan yang cukup mendalam yang mereka bawa di sepanjang hari-hari mereka, dan panggilan untuk kembali merupakan sebuah perayaan yang mereka dambakan untuk dapat kembali kepada TUHAN.

Dalam ayat 3 dikatakan "Bawalah serta perkataanmu dan kembalilah kepada TUHAN! Katakanlah kepada-Nya, buanglah segala kesalahan dan ambilah sesuatu yang baik, maka kami akan menghadiahkan lembu muda dan pengakuan kami." Di sini, imperative diintesifkan oleh sebuah perubahan berbentuk jamak dalam bahasa ibrani (ambil! Kembali!

\footnotetext{
${ }^{9}$ A.A Machintosh. 1997. Critical and Exegetical Comementary on Hosea (Edinburgh: T\&T Clark), HIm. 571

${ }^{10}$ Ibid. HIm. 559

${ }^{11}$ James Luther Mayes. 1969. Hosea: A Commentary (London: SCM Press), HIm. 59-60
} 
Katakan!). Sang nabi memperlihatkan kepada Israel bagaimana pengakuan pertobatan yang diperlukan harus dikatakan melalui doa. Nabi Hosea kini mengutip kata-kata untuk doa pertobatan yang harus mereka terima sebagai persembahan mereka kepada Allah, di mana doa penuh penyesalan kepada Allah juga akan dijawab dengan nubuat keselamatan, Mazmur 85 .

Dalam bagian berikutnya yaitu ayat 4, "Assyur tidak akan menyelamatkan kami. Kami tidak mau menunggangi kuda dan tidak akan berkata lagi: ya Allah kami! Terhadap pekerjaan tangan kami, karena Engkau menunjukkan belas kasihan ditengah-tengah anak yatim." Apa makna sebenarnya dari perkataan Hosea "Asyur tidak akan menyelamatkan kami'? Dari doa yang dikutip oleh Hosea, sebenarnya ia sedang mengajarkan bahwa bangsa Israel harus melepaskan ketergantungan mereka terhadap kekuasaan politik atau agama lain apapun sebagai syarat pemulihan hubungan mereka dengan TUHAN. di ayat ini, Hosea menyatakan bahwa TUHAN adalah sumber keamanan bagi Israel yang sesungguhnya dan bukan dewa-dewa Asyur. Dalam bagian ini, ia mendorong umat Israel kiranya permohonan umat beriman itu sudah seharusnya ditujukan hanya kepada TUHAN Allah mereka yang satu-satunya dan ekslusif, dan bukan kepada berhala kayu yang diasuh oleh tangan manusia. Penolakan yang diatur oleh teriakan hati yang berfungsi sebagai perlengkapan afirmasi positif, seperti anak yatim yang tidak berdaya, menunjukkan kita selalu dalam belas kasihan Tuhan. rujukan yang sama juga mengutip kekuatan militer pasukan kereta perang kuno, apakah mereka orang mesir ${ }^{12}$ atau kereta-kereta yang mungkin dipaksa orang Israel untuk diproduksi sebagai upeti ${ }^{13}$, atau mungkin permohonan yang putus asa untuk bantuan yang dikirim secara internasional untuk mengirim penunggang kuda. ${ }^{14}$

Ayat 5, "Aku akan menyembuhkan kemurtadan mereka, au akan mengasihi mereka dengan sukarela, karena kemarahan-Ku telah surut dari pada mereka." Ayat ini digambarkan sebagai jantung dari seluruh bagian pesan yang ada. Ketika orang-orang yang berada dalam penderitaan mengakui sifat mereka yang memberontak atau tidak taat kepada TUHAN, maka Ia akan menghapuskan hukuman dan penderitaan mereka. Dengan keyakinan pribadi yang kuat akan tindakan Allah dan kehadiran-Nya di antara kita (I will heal, I will love, I will be) dalam ayat ini dan ayat berikutnya, Mays dengan tepat meyebut ini sebagai "terapi cinta" Tuhan untuk semua orang. ${ }^{15}$ kemurkaan TUHAN menyingkapkan sifat keras kepala Israel dan kasih-Nya akan menyembuhkannya. Di sini, pengalaman cinta dengan TUHAN dan penyembuhan merupakan hal yang diingat dari masa-masa kekacauan. Akan tetapi, cara yang sesungguhnya untuk memulihkan keselamatan masih harus dialami oleh Israel sampai bangsa itu bertobat dari penyembahan berhala mereka yang jahat dan mengakui kebergantungan mereka yang sepenuhnya kepada Allah.

Ayat 6, "Aku akan menjadi seperti embun pagi Israel, ia akan mekar seperti bunga lili dan berakar seperti pohon Lebanon." Dalam ayat ini, TUHAN berkata-kata memulai proses keselamatan untuk menyembuhkan Israel. Hal ini berlaku universal untuk kondisi manusia dan hubungannya dengan Allah. Di sini TUHAN, hadir sebagai jawaban yang akan memelihara Israel. Dalam bagian ini, tindakan TUHAN setelah Israel bertobat, digambarkan dengan sangat indah, yang disajikan dengan gambaran yang sangat romantis yang memberikan gambaran mewah dari kebun, mirip dengan motif yang ditemui dalam nyanyian

\footnotetext{
12 James Luther Mayes. 1969. Hosea: A Commentary (London: SCM Press), HIm. 187

13 Marvin A. Sweeney. 2000. The Twelve Prophet: Hosea, Joel, Amos, Obadiah, Jonah (Collegeville, MN: The Liturgical Press), HIm. 138.

${ }^{14}$ A.A Machintosh. 1997. Critical and Exegetical Comementary on Hosea (Edinburgh: T\&T Clark), HIm. 566

${ }^{15}$ James Luther Mayes. 1969. Hosea: A Commentary (London: SCM Press), HIm. 184-190
} 
kasih yang beberapa kali muncul dalam Kidung Agung. ${ }^{16}$ Di musim panas Israel yang panjang tanpa adanya turun hujan, embun di pagi hari dan pada malam yang sejuk mengandung prinsip persediaan air untuk kehidupan. Makanan untuk kehidupan yang disediakan oleh embun dinyatakan juga dalam Ulangan 32:2; 33:28; Mazmur 110:3; 133:3, dan di tuliskan dengan sedemikian rupa sehingga Yesaya mengaitkannya dengan kebangkitan (Yesaya 26:19). Sambil dipelihara oleh embun kemurahan hati-Nya Tuhan, Israel akan berbunga seperti bunga lili yang mekar. Meskipun keindahan bunga-bunga di kebun bersifat sementara, Israel akan berakar seperti pohon-pohon aras Lebanon yang terkenal, yang pada masa itu dianggap sebagai pohon yang ditanam oleh Allah (Mazmur 104:16) dan akan senantiasa ada. Akar dari pertobatan Israel di sini diharpkan dapat meluas dan berkembang.

Ayat 7, "Ranting-rantingnya akan menyebar, keindahannya akan seperti pohon zaitun dan harumnya seperti Lebanon." Bagian ini merupakan sebuah tatanan di mana TUHAN akan menyatakan dirinya lagi merupakan padang gurun ketika keluaran, di mana keharuman belas kasih-Nya akan tampak jelas bagi semua orang. Di sinilah Israel akan digoda lagi oleh pengalaman mengerikan dari kuasa perbuatan-Nya. Gagasan "mekar atau menyebar" merupakan gambaran sebuah babak baru. ${ }^{17} \mathrm{Di}$ tempat yang sangat subur inilah TUHAN akan memulihkan umat Israel bertobat dan menjadikannya berstu kembali dengan diri-Nya. Kemudian istilah ibrani untuk keindahan pohon zaitun juga digunakan untuk menggambarkan keagungan raja (Mazmur 21:5, 45:3-9) dan TUHAN sendiri (Mazmur 104:1). Selain itu jika diperhatikan bagaimana sesuatu yang serupa di jumpai dalam pasal 5-7, bahwa sesuatu itu akan jatuh ke dalam ladang yang alami, dari akar yang pertama akan menghantam, lalu cabarng atau ranting-rantingya akan menyebar, dan kemudian tumbuh subur untuk menciptakan sebuah naungan untuk perlindungan.

Ayat 8, "Mereka akan kembali diam di dalam naungan-Ku dan hidup kembali seperti gandum, mereka akan berumbuh seperti pohon anggur yang termahsyur seperti anggur Lebanon." Ayat ini menyajikan gambaran taman yang tumpang tindih dan kesenangan TUHAN. hal ini mirip dengan gambaran kebun-kebun anggur yang dijanjjikan dalam Hosea 2:15 dan keharumannya yang menawan dari hutan-hutan Lebanon dalam kitab Kidung Agung (4:11). Tidak seperti gambarn-gambaran ini, gambaran dalam Hosea 9:7 bisa juga berfungsi sebagai polemic untuk melawan ketergantungan pada praktek-praktek kesuburan Baal. Konsep perlindungan dalam naungan Tuhan sudah tidak asing lagi bagi penyembahpenyembah Isreal, dari Mazmur 36:7 dan 91:1, mereka mengajukan permohonan untuk berlindung dibawah naungan sayap-sayap-Nya. Di sana kemamanan dan ketentraman tersedia dengan berlimpah-limpah, seperti yang terdapat dalam Hosea 2:22, gambara dari buah zaitun, biji-bijian dan anggur yang disajikan bersama dalam ayat ini, melambangkan tiga pokok hasil pertanian dan pengorbanan bait suci di Israel. ${ }^{18}$ Pada kali ini Israel akan sekali lagi menjadi tanaman anggur yang berharga itu, seperti apa yang sejak awal sudah seharusnya menjadi sejarah mereka. ${ }^{19}$

Ayat 9, "Efraim, apakah hubungan-Ku dengan berhala-berhala? Aku yang menjawab dan memelihara kamu! Aku seperti pohon cemara yang hijau, daripada-Ku kamu mendapat buah!." Dalam bagian ini, mengapa Hosea mengangkat topik yang menggambarkan Tuhan seolah-

\footnotetext{
${ }^{16}$ Hans Walter Wolff. 1974. Hosea: A Commentary on the Book of Hosea (Philadelphia: Fortress Press), HIm. 234

${ }^{17}$ Douglas Stuart. 2009. Hosea-Jonah (Nashville, TN: Thomas Nelson), HIm. 215

${ }^{18}$ Marvin A. Sweeney. 2000. The Twelve Prophet: Hosea, Joel, Amos, Obadiah, Jonah (Collegeville, MN: The Liturgical Press), HIm. 140

${ }^{19}$ Hans Walter Wolff. 1974. Hosea: A Commentary on the Book of Hosea (Philadelphia: Fortress Press), HIm. 236
} 
olah membuat perhitungan dengan Irael. Hosea sedikit berani menggambarkan emosi yang dirasakan Tuhan, dan menampakkan rasa kejengkelan yang TUHAN miliki ketika menghadapi bangsa yang memberontak dan keras kepala untuk menyembah berhala. Seruan Tuhan terhadap Efraim telah didapati di seluruh kitab Hosea, misalnya Hosea 6:4 yang terdapat dalam bagian akhir dialog dan juga di dalam Hosea 11: 8, di mana perjuangan di dalam hati Tuhan secara kontras disaksikan melebur menjadi kasih sayang. Di sini mungkin saja hal itu bercampur dengan protes dan juga kelegaan. Seperti yang telah diingatkan oleh TUHAN kepada Israel bahwa allah-allah palsu atau dewa-dewa yang dibuat oleh manusia tidak dapat memberikan jawaban atau tanggapan secara emosi atas kerusakan dan kebutuhan mereka, tidak seperti Allah Israel yang hidup. Di sini Hosea juga menggunakan gambaran pohon cemara, dalam konteks Israel pada masa itu, pohon cemara dianggap sebagai tempat bernaung yang menyegarkan di alam liar yang akan diberikan TUHAN kepada mereka yang mencari-Nya sebagai satu-satunya pasangan sejati mereka dalam hidup.

Ayat 10, "Siapakah yang bijaksana? Biarlah ia memahami ini. Apapun yang dipahaminya ia akan mengetahuinya. Karena jalan-jalan TUHAN benar dan orang benar berjalan di dalamnya, tetapi pemberontak akan tersandung di dalamnya." Bagian ini merupakan penutup dari kitab Hosea yang kira-kira diberikan sebagi petunjuk bagi pembaca. Dalam kata-kata penutup Hosea ini seolah menyiratkan bahwa nubuat itu telah menjadi sebuah panduan atau literature hikmat. Jadi di sini pembaca yang bijaksana akan memahami bagaimana berita Hosea itu saling berkaitan dan penuh pengharapan, bahkan setelah kejatuhan Samaria sekalipun. Kitab ini dimaksudkan untuk mengarahkan pembaca pada kesimpulan, bahwa TUHAN dibenarkan dalam menyebabkan kehancuran Israel dan bahkan untuk menunjukkan bahwa mereka adalah umat yang berdosa akan mencapai penyelesaian yang berlawanan. Bagian penutup ini kira-kira dirancang Hosea untuk mendorong pembaca yang mengecam untuk dapat menemukan kebijaksanaan dan kesalehan TUHAN di sepanjang pelayanan Hosea.

\section{Kesimpulan}

Meskipun Israel telah berbuat jahat dan tidak setia kepada Tuhan, hal tersebut tidak mengubah kemurahan hati dan rasa cinta TUHAN terhadap Israel. Dari kehancuran yang Israel alami melalui Asyur, yang terjadi sesuai kehendak Tuhan, hal tersebut merupakan bagian dari hukuman yang harus ditanggung oleh Israel sebagai wujud bagian kasih Tuhan kepada mereka. Karena melalui peristiwa tersebut, Tuhan memilih Hosea untuk menawarkan dibangunnya kembali hubungan perjanjian antara Tuhan dan umat Israel. Di sini, pengalaman cinta dengan Tuhan dan juga perihal penyembuhan merupakan hal yang akan diingat dari masa-masa kekacauan. Akan tetapi, cara yang sesungguhnya untuk memulihkan keselamatan masih harus dialami oleh Israel sampai bangsa itu bertobat dari penyembahan berhala mereka yang jahat dan mengakui kebergantungan mereka yang sepenuhnya kepada Allah. Syarat berikutnya yang harus dipenuhi, mereka harus memberikan pertobatan secara utuh dan mau melepaskan ketergantungan mereka terhadap kekuasaan politik atau agama dan penyembahan yang lain.

Yang menjadi klimaks dalam pasal ini, ketika Tuhan melihat kondisi Israel yang hancur menimbulkan perjuangan batin di dalam diri-Nya. Karena hal tersebut, Ia sang pemilik kasih berusaha memulihkan pengharapan mereka, bahwa kehancuran Israel pada masa itu bukanlah akhir dari segalanya. Pada bagian ini Tuhan sendiri yang akan hadir sebagai jalan keselamatan dan kesembuhan dari luka mereka. Dalam kondisi hancur 
sekalipun Tuhan berusaha hadir kembali untuk mengungkapkan kasih yang tidak dipahami oleh umat Israel. Jika Israel sepakat untuk kembali kepada Tuhan, mengakui kedaulatan Allah dalam penderitaannya, maka Ia akan bersatu kembali dengan mereka untuk memulai proses kesembuhan mereka, dan Ia berjanji akan hadir bagaikan embun pagi sebagai pemelihara dan sumber kehidupan bagi mereka serta menjadi naungan dan perlindungan bagi umat kesayanganya. Ia akan memulihkan identitas Israel sebagai benih yang berharga seperti apa yang Tuhan telah tentukan sejak awal atas mereka.

\section{IMPLIKASI}

\section{Aplikasi Teologis}

Tuhan Allah Israel adalah Pribadi yang sangat mengasihi umat yang pernah mengikat perjanjian dengan-Nya, ketika melihat umat-Nya putus perjanjian dengan diri-Nya akibat dari ketidak taatan dan penghianatan mereka, kemarahan yang ada dalam hati-Nya menimbulkan pergulatan batin dalam diri Allah, meskipun Allah sangat membeci kesombongan, ketidak taatan dan penghianatan yang dilakukan umat pilihan-Nya. Dari gambaran ini bisa dilihat, Allah Israel merupakan Pribadi yang penuh kasih, namun seringkali luas kasih-Nya tidak dipahami oleh umat pilihan-Nya. Ia akan memberikan penghukuman kepada umat-Nya yang bersalah bukan karena didasari oleh rasa benci yang besar, tetapi didasari oleh rasa cinta yang besar, yang ingin Tuhan ungkapkan kembali kepada umat pilihan-Nya agar supaya dapat membawa mereka kembali ke dalam naungan-Nya dan membangun ikatan perjanjian kembali yang sudah pernah diputuskan. Dari itu semua Tuhan adalah Pribadi yang selalu rindu untuk melihat kesembuhan dari umat-Nya dan ingin tetap menjadi sumber jawaban bagi setiap orang yang mengakui-Nya dalam kepercayaan mereka.

\section{Aplikasi Praktis}

Usaha dari bangsa Israel untuk mendapat kemakmuran hidup dengan berpaling dari Tuhan dan mengandalkan bantuan dari bangsa-bangsa lain, merupakan sebuah pintu kehancuran bagi mereka. Meskipun mereka secara sesaat menikmati kemakmuran itu, pada akhirnya semua itu berubah menjadi bencana bagi mereka. Kesombongan akan kemampuannya sendiri, ketidaktaatan dan penghiatan mereka kepada Tuhan, mengakibatkan terputusnya ikatan perjanjian mereka dengan Tuhan, selain itu juga mendatangkan penghukuman yang harus mereka tanggung sebagai jalan dikembalikannya hubungan mereka dengan Tuhan Allah Israel. Untuk menjalin kembali hubungan mereka dengan Tuhan, Ditengah penderitaan yang harus mereka tanggung, mereka harus mengakui kedaulatan Tuhan secara penuh dan melakukan pertobatan secara utuh untuk kembali kepada Tuhan Allah Israel. Dengan demikian, Tuhan akan bersedia memproses kesembuhan luka, reconnecting hubungan mereka dengan Tuhan dan memulihkan statusnya sebagai benih berharga yang di miliki Allah.

\section{DAFTAR PUSTAKA}

Lasor, W.S, dkk. 2004. Pengantara Perjanjian Lama 2. Jakarta: BPK Gunung Mulia.

King, J. Philip, dkk. 2012. Kehidupan Orang Israel Alkitabiah. Jakarta: BPK Gunung Mulia.

Thirdmill. 2007. Hikmat Nubuat Hosea. Casselberry: Third Millenium Ministries. 
Dawan, Christine V, Firman Panjaitan. 2018. Kasih Setia Khesed, Hosea 6:4-6. Yogyakarta: Diandra Kreatif.

Hill, Andrew E, John H Walton. 2013. Survei Perjanjian Lama. Malang: Gandum Mas.

Macintosh, A.A. 1997. Critical and Exegetical Comementary on Hosea. Edinburgh: T\&T Clark.

Mays, James Luther. 1969. Hosea: A Commentary. London: SCM Press.

Sweeney, Marvin A. 2000. The Twelve Prophet: Hosea, Joel, Amos, Obadiah, Jonah. Collegeville, MN: The Liturgical Press.

Wolff, Hans Walter. 1974. Hosea: A Commentary on the Book of Hosea. Philadelphia: Fortress Press.

Douglas Stuart. 2009. Hosea-Jonah . Nashville, TN: Thomas Nelson. 